\title{
PARTY GOVERNMENT UNDER THE AMERICAN CONSTITUTION*
}

\author{
Lloyd N. CuTler ${ }^{\dagger}$
}

When Owen Roberts left the Supreme Court, he chose not to retire but to resign. He made this financial sacrifice to work for a federal union of the world's democracies, to be built on the fundamental lines of the American Constitution. ${ }^{1} \mathrm{He}$ and his colleagues, who included Clarence Streit, George Marshall, and John Foster Dulles, urged the creation and popular election of a transnational Congress. ${ }^{2}$ They also proposed a transnational executive, to be elected either by the Congress or by the people of the member states. ${ }^{3}$ They expected that transnational political parties would arise and that party government would be the organizing principle of the new federal union. ${ }^{4}$

During Owen Roberts' time in public life, party government was the organizing principle of American national politics. By party government, of course, I mean a government in which the same party holds the White House and a majority in both houses of Congress. From the time Justice Roberts took his first public job as assistant district attorney to 1945, when he left the Supreme Court, party government prevailed during twenty of twenty-three Congresses, all but the last Congresses of the Taft, Wilson, and Hoover Administrations. ${ }^{5}$ During that period no President was elected without carrying a majority for his party in both houses of Congress. ${ }^{6}$

Since 1945, party government in America has been the exception rather than the rule. In the twenty Congresses elected after 1945, party government has prevailed during only nine. ${ }^{7}$ In the nine Congresses

* Originally delivered as the Owen J. Roberts Memorial Lecture at the University of Pennsylvania Law School on February 28, 1985.

$\dagger$ Partner, Wilmer, Cutler \& Pickering. A.B. 1936, LL.B. 1939, LL.D. (Hon.) 1983, Yale University. Mr. Cutler served as counsel to the President in the Carter Administration from 1979 to 1981. (1955).

I See Streit, Owen J. Roberts and Atlantic Union, 104 U. PA. L. Rev. 354, 360

2 See O. Roberts, J. Schmidt \& C. Streit, The New Federalist 50 (1950).

S See id. at 65.

- See id. at 53-54.

- See Bureau of the Gensus, U.S. Dep'T of Commerce, Historical Statistics of the United States: Colonial Times to 1970 (Part 2) 1083 (1975) [hereinafter cited as Historical Statistics].

- See id.

7 See Congressional Quarterly INC., Elections '84, at 183-84 (1984) 
elected from 1968 to date, party government has prevailed during only two. In the five presidential campaigns from 1968 to date, only one presidential victor carried a majority for his party in both houses of Congress. $^{8}$

This remarkable decline in the frequency of party government has been accompanied by a parallel decline in party loyalty among voters and among each party's members of Congress. ${ }^{\circ}$ Indeed, the evidence suggests that this decline in party loyalty is closely related to the decline in party government.

At the turn of the century, when Owen Roberts was teaching at this law school, party loyalty was habitual among voters and members of Congress. From 1900 to 1908, an average of only four percent of the nation's congressional districts split their tickets to give a majority to one party's candidate for President and to the other party's candidate for the House of Representatives. ${ }^{10}$ Ticket splitting increased gradually during the first half of this century. After World War II, it exploded. ${ }^{11}$ In the 1984 election, over forty percent of all congressional districts voted in favor of President Reagan's reelection and the election of a Democratic member of Congress. ${ }^{12}$ Polling data show that over onequarter of all voters now identify themselves as independent rather than as members or supporters of any party, ${ }^{13}$ and that more than half of all voters now split their presidential and congressional ballots. ${ }^{14}$ When Presidents Eisenhower, Nixon, and Reagan were reelected by margins as high as sixteen to twenty-three percent, ${ }^{15}$ the same voters

(party affiliation of Presidents up to 1980); N. Ornstein, T. ManN, M. Malbin, A. Schick \& J. Bibby, Vital Statistics on Congress, 1984-1985 Edition 33-35 (1984) (party affiliation of members of Congress) [hereinafter cited as VITAL STATISTics on Congress]; 40 Cong. Q. Almanac 6-B, 11-B, 16-B (1984) (results of 1984 elections).

S See sources cited supra note 7.

- See N. Nie, S. Verba \& J. Petrocik, The Ghanging American Voter 4773 (1979); D. Price, Bringing Back the Parties 51-93 (1984).

${ }^{10}$ See Vital Statistics on Congress, supra note 7, at 56.

II See id. In 1944 approximately $11 \%$ of the nation's congressional districts were carried by a presidential candidate of one party and a House of Representatives candidate of another party. Over the next three presidential elections the average percentage of ticket splitting jumped to over $23 \%$. Id.

12 The 1984 figures were derived from M. Barone \& G. Ujifusa, The AlmaNAG of AMERican Politics 1986 (1985).

13 See G. Gallup, The Galiup Poll: Public Opinion 1984, at 257 (1985).

14 See Ranney, What Constitutional Changes Do Americans Want?, ThIs Constitution: A Bicentennial Chronicle, Winter 1984, at 13, 18 (estimating that two-thirds of all voters split their presidential and congressional ballots in 1980).

15 See M. Barone \& G. UjifuSA, supra note 12, at 1-ii (indicating Nixon's $23 \%$ margin of victory in 1972 and Reagan's $21 \%$ margin of victory in 1984); HISTORICAL STATISTICS, supra note 5, at 1073 (indicating Eisenhower's 16\% margin of victory in 1956). 
returned Democratic party majorities to the House all three times and to the Senate twice. ${ }^{16}$

In Congress, the decline in party loyalty has been almost as dramatic. Congressional Quarterly computes the annual percentage of House and Senate ballots in which a majority of one party's members were on one side of the issue and a majority of the other party's members were on the other side. At the turn of the century the figure was in the range of seventy percent. ${ }^{17}$ It is only forty-four percent today. ${ }^{18}$ As between the President and his fellow party members in the House and Senate, the loyalty percentage on presidentially supported measures has averaged below seventy-five percent since $1954 .^{18}$ This means that, whether or not the President's party has a majority in both houses, he usually needs to form a coalition with a sizable bloc of the opposite party in order to enact most elements of his party's program.

One may well ask whether these parallel declines in party government and party loyalty are of more than historical interest. I submit they are of enormous current importance, and that they go far to explain the national disappointment in the ineffectiveness of Congress and of the national government as a whole.

That disappointment, confirmed by polling data, ${ }^{20}$ centers on the evident inability of the President and Congress to get together on a coherent program for governing, and to stand accountable to the voters for the results of that program. With divided government and the lack of cohesion among each party's members of Congress, national policy has to be made one issue at a time. Each issue is decided by a crossparty coalition whose makeup shifts from one issue to the next. The result is a hodgepodge of ad hoc policy decisions that are usually inconsistent with one another, and a sum of outcomes that most voters condemn. Neither the President nor any legislator defends this sum of conflicting outcomes or accepts responsibility for bringing it about.

There are many examples over the nine most recent Congresses, seven of them periods of divided government. Time and space allow mention of only two: the shape of the budget-the most important domestic issue that any modern government has to decide-and the mak-

16 See VITAL Statistics on CongRess, supra note 7, at 34-35 (data for 1956 and 1972 elections); 40 Cong. Q. Almanac 11-B, 13-B (1984) (data for 1984 elections).

17 See D. Price, Bringing Back the Parties 51 (1984).

18 See id.

19 See Vital Statistics on Congress, supra note 7, at 180-81.

20 See, e.g., G. Gallur, The Gallup Poll: Public Opinion 1980, at 178 (1981) (only 14\% of those polled had a "great deal of confidence" in the federal government). 
ing of agreements with other governments-a sine qua non of foreign policy and security and even of economic policy as the world becomes ever more interdependent.

The federal government now spends more than five dollars for every four it takes in, even in a period of high economic growth. ${ }^{21}$ This condition arises out of a series of ad hoc decisions, each made by a different cross-party coalition, on the levels of particular taxes and expenditures. The longer this condition continues, the harder it will be to correct. Net interest payments already consume $3.4 \%$ of gross national product (GNP) and 14\% of the total 1985 budget-double the percentage of the much smaller 1970 budget. ${ }^{22}$ According to the Gongressional Budget Office, interest payments will reach $4.1 \%$ of GNP and $17 \%$ of the much larger 1990 budget. $^{23}$ The 1985 deficit alone will be as great as the total of all government expenditures in $1971 .{ }^{24}$ Most economists warn that, while continuing large deficits stimulate the economy in the short run, the long-term impact on interest rates, exchange rates, trade balances, and inflation will be disastrous. All elected politicians, from the President to the most junior member of Congress, agree that this growing cancer must be removed, and they each have a plan to do so. Each of these plans would reduce the annual deficit by twenty-five to fifty percent per year over the next several years, but they would do so in differing ways. ${ }^{25}$ Any of these plans would be better than letting the deficits continue to accumulate at their present annual rate. But those we elect cannot form a consensus about which plan to adopt, and the cancer continues to grow.

Many of our most important agreements with other nations take the form of treaties. The Constitution requires that to become effective, treaties signed by the President must win the consent of two-thirds of the Senate. ${ }^{26}$ This means that thirty-four Senators can upset a treaty the President has negotiated with another nation or nations. Even during periods of party government, this minority prerogative is frequently

21 See Office of Management and Budget, Executive Office of the President, Historical Tables, Budget of the United States Government, FISCAL YEAR 1986, at 1.1(1) (1985).

22 See Congressional Budget Office, Congress of the United States, The ECONOMIC AND Budget OUTLOOK: Fiscal YeARS 1986-1990, A Report to THe Senate and House Committees on the Budget-Part I, at 54-56 (1985).

23 See id.

24 See Office of Management and Budget, supra note 21, at 1.1(1).

${ }^{25}$ See, e.g., N.Y. Times, Apr. 15, 1985, at A1, col. 1, B9, col. 1 (reporting Senator Dole's support of a "deficit-reducing package" that would reduce spending by nearly $\$ 300$ billion over three years, and House Democrats' support of an across-theboard freeze on spending).

${ }^{26}$ U.S. CoNST. art. II, $\S 2$, cl. 2. 
exercised, sometimes by the minority party voting as a bloc, but more often by an ad hoc cross-party coalition. When the President's party does not have majority control of the Senate, as was true when the League of Nations Covenant was considered, treaty approval faces even higher odds. Over forty treaties submitted to the Senate since World War II either have been rejected or have never come to a vote. ${ }^{27}$ Among the important treaties that have never been ratified are SALT II, the 1974 and 1976 treaties with the Soviet Union on underground nuclear tests and explosions, the maritime boundary treaties with Mexico and Cuba, the Genocide Convention, a number of UN and OAS Human Rights Conventions, the Vienna Convention on the Interpretation and Enforcement of Treaties, and a wide variety of bilateral trade, tax, and environmental treaties. ${ }^{28}$

With the decline in party government and party cohesion, neither the President nor any member of Congress need accept the blame for this hodgepodge of national policies, and none of them does so. Each of them can fairly say that he or she did have a coherent program, but that the others blocked its adoption. Their success in shifting the blame has been truly remarkable. Seven incumbent Presidents have run to succeed themselves since World War II, and five of them-Truman, Eisenhower, Johnson, Nixon, and Reagan-have won another term. ${ }^{29}$ That is a success rate of over seventy percent. Four of the five-all but Johnson-were victorious while presiding over a divided government. ${ }^{30}$ Since World War II, ninety percent of the Senate and House incumbents of both parties who ran for another term were successful, whether their own party won or lost the presidential election. ${ }^{31}$ That was true even for the incumbents of the losing party in the landslide presidential elections of 1956,1964, 1972, and 1984. In 1984, the reelection success rate of House incumbents of both parties was a whopping ninety-five percent. ${ }^{32}$ Polls show that the Congress as an institution has a very low approval rating among voters, ${ }^{33}$ but almost without fail the voters re-

${ }^{27}$ See Letter from Robert E. Dalton, Esq., Assistant Legal Advisor for Treaty Affairs, U.S. Department of State, to Lloyd Cutler, Esq. (Nov. 13, 1984) (with attachments).

28 See id.

29 See Congressional QUARTERLY INC., supra note 7, at 183-84.

so See id.; VrTAl STATISTICS ON CoNGREss, supra note 7, at 35 (party affiliation of members of Congress); 40 Cong. Q. Almanac 6-B, 11-B, 16-B (1984) (results of 1984 elections).

s1 See Vital Statistics on Congress, supra note 7, at 49-51. The success rate is $92 \%$ for House incumbents and $79 \%$ for Senate incumbents. The weighted average for both houses is $89.4 \%$. See id.

32 See N.Y. Times, Nov. 8, 1984, at A29, col. 1.

ss See, e.g., N.Y. Times, Feb. 20, 1980, at A18, col. 1. 
elect their own individual members of Congress. In contrast, when the Canadian Liberal Party fell from power in the 1984 election, the percentage of incumbents who ran and won reelection was a mere sixty percent, ${ }^{34}$ and for Liberal Party incumbents, it was only twenty-six percent. ${ }^{35}$

With reelection success rates like these, each party's incumbent legislators have no need to follow Benjamin Franklin's famous maxim: "We must indeed all hang together or most assuredly we shall all hang separately." Indeed, their preferred path to survival is to take the advice of the Damon Runyon character who said, "It's every man for theirself."

Does the presence or absence of party government and party loyalty really matter to the effectiveness and accountability of government? Listen to Woodrow Wilson, speaking at a time when party government was the rule and divided government was the exception. In 1912 Wilson ran for President during the first divided government of the twentieth century. ${ }^{36} \mathrm{He}$ had the benefit of a Democratic majority in the House of Representatives and a Republican rift that put both the incumbent President Taft and his predecessor Theodore Roosevelt into the race for the presidency. One of Wilson's campaign themes was the danger of divided government. In a speech in Philadelphia before an audience including many Progressive Republicans, he said:

The most interesting thing about the Government of the United States is that under its constitutional balances it postpones everything. You can capture your House of Representatives in any second-year period, but you cannot capture your Senate in two years; and it may be that at the time you capture your House you haven't a chance to capture your Presidency. The present House of Representatives is Democratic because the Republican party broke its promises. But, even with the assistance of the independent Republicans in the Senate of the United States, it wasn't possible to put the program for which the country had been waiting past the veto of the President. So that you have an arrested government. You have a government that is not responding to the

34 See Letter from Allan Gotlieb, Canadian Ambassador to the United States, to Lloyd Cutler, Esq. (Dec. 18, 1984).

ss See Letter from Allan Gotlieb, Ganadian Ambassador to the United States, to Lloyd Cutler, Esq. (Jan. 16, 1985); cf. The Times (London), Sept. 6, 1984, at if (reporting that the Liberal Party held just 40 seats after the election as compared with the 135 it previously held).

s6 See Vital Statistics on Congress, supra note 7, at 33. 
wishes of the people. You have a government that is not functioning, a government whose very energies are stayed and postponed. If you want to release the force of the American people, you have got to get possession of the Senate and the Presidency as well as of the House. ${ }^{37}$

Wilson won the presidency and a good majority for the Democrats in both the Senate and the House. ${ }^{38}$ His first term carried out the party program by laying the legislative foundations of The New Freedom, generally regarded as the most productive period of national government between the abolition of slavery and the New Deal. The principal means adopted to legislate the Wilson program was the binding party caucus, a Democratic reform that filled the power vacuum left by the progressive movement's successful attack on the arbitrary power of Speaker Joe Cannon. ${ }^{39}$ The binding party caucus was used so effectively that it won the epithet "King Caucus," and soon fell victim itself to the progressive drive to remove all party restraints on the individual conscience of each legislator. ${ }^{40}$ By the time of Wilson's last Congress, divided government had returned, "King Caucus" had fallen apart, and Wilson failed to achieve approval of his most important initiative, joining the League of Nations. ${ }^{41}$

A comparison of presidential success rates under party government and divided government bears Wilson out. Even under divided government, newly elected Presidents enjoy a brief "honeymoon" with Congress, but it rarely lasts more than six months to a year. By that time incumbents of both parties become too concerned about the next House or Senate election to vote with the President at the risk of losing the support of an important interest group. Wilson's first two years and FDR's first term are the only peacetime examples of longer honeymoons in this century, and both occurred during periods of party government. ${ }^{42}$ Over the full term, the President's position has succeeded under party government on about eighty percent of all major congressional votes since 1953; under divided government the rate has been

${ }^{37}$ W. Wilson, A Crossroads of Freedom 496 (1956). (1981).

${ }^{38}$ See J. Sundquist, The Deciine and Resurgence of Congress 130-31

ss "[T] he Democratic caucus adopted a set of rules, ... [including] one that permitted a two-thirds majority to bind all members of the caucus. . . To violate the caucus directive would be to be 'read out of the party,' with accompanying loss of perquisites, including choice committee assignments." Id. at 169.

${ }^{40}$ See id. at 168-76.

41 See id. at 95.

42 See id. at 32, 127. 
about sixty-six percent. ${ }^{43}$ The notable exception, of course, was President Reagan's success rate of eighty-one percent in $1981 .^{44}$ But after this honeymoon, his rate quickly reverted to divided government form, and he appears unlikely to match his 1981 success during his second honeymoon in $1985 . .^{\text {s }}$

In the parliamentary systems of Western Europe and Japan, of course, the Prime Minister's success rate is very close to one hundred percent. Efficiency is not the only measure of a system of government. But if we were to measure the efficiency of democratic governments by the ability of elected leaders to legislate their party's program, the American system today is only four-fifths as efficient as the parliamentary systems when we achieve party government, and only two-thirds as efficient when we have divided government. Even these figures overstate the President's actual success, since the bills finally adopted often contain substantial modifications of the President's initial proposals, which he accepts to salvage at least half a loaf. ${ }^{46}$

But there are many thoughtful citizens who think that our present condition of divided government and the resulting hodgepodge of national policies is preferable to the consequences of a return to party government and party cohesion. They accept the hodgepodge as the best available consensus that can be achieved among the diverse interest groups that make up so huge and variegated a nation. They see the consensus as conceding enough to each group to avoid the degree of divisiveness that would impair the national unity. They fear that party government and party cohesion would give an administration too much power to work its will, and lead to the kind of extreme swings in national policy that have occurred since World War II in the United Kingdom, along with the bitterness that has grown among Britain's competing interest groups. They also note that only a decade ago divided government helped to expose the excesses of an arbitrary and corrupt President and force his resignation. They read the results of the 1984 election, with its wide degree of ticket splitting, as showing that many who voted for President Reagan affirmatively wanted the insur-

4s See Vital Statistics on Congress, supra note 7, at 177-78. These percentages probably overstate the President's actual success record, since many of the votes occurred after the President had substantially compromised in order to salvage at least part of his original proposal. For example, the Tax Equity and Fiscal Responsibility Act of 1982, Pub L. No. 97-248, 96 Stat. 324, which increased taxes by at least half of the amount cut in the 1981 tax act, is scored as a Reagan "success" because, after opposing any 1982 tax increase at all, he supported the final bill to obtain some of the expenditure cuts he wanted.

14 See Vital Statistics on Congress, supra note 7, at 178.

40 See id.

18 See supra note 43. 
ance policy of a Democratic majority in the House. They would interpret the reelection of the President and more than ninety percent of the congressional incumbents of both parties in 1984 as a public endorsement of divided government and loose party ties.

This benign view of divided government was also shared by at least some of the Framers. The Constitution makes no mention of party. It was drafted when political parties were first emerging in the British Parliament. They were feared the way we fear "special interest" groups today. They did not fit the Madisonian ideal of the President and Congress as men who would rise above the pressures of "faction" (Madison's euphemism for "party") and decide every issue in the national interest as each of them individually saw it. ${ }^{47}$ A majority of the Framers did not want any individual to hold enough power to have his way completely, nor did they want any party to hold that much power. That is why they decided to share all major governmental powers among the branches and, in the legislative branch, between two coequal chambers. That is why they arranged for the President and each House to be elected by different constituencies and for different periods of time.

Nevertheless, party government grew rapidly, because it proved essential in practice to make the new Constitution work. John Adams, Jefferson, Madison, and Monroe were among its most successful practitioners. In the seven consecutive administrations of these four Presidents, divided government never occurred. ${ }^{48}$ In their presidencies, each was the de facto leader of his party in the Congress. Although Adams and Jefferson were more activist vis-à-vis Congress, while Madison and Monroe were more deferential, all four maintained a high degree of party cohesion. Adams and Jefferson never had to cast a veto, Madison did so only seven times, and Monroe only once. ${ }^{49}$ Since World War II, most Presidents have cast vetoes by the dozens. ${ }^{30}$

Over our history power has tended to shift between the presidential and the congressional wings of each party's axis. But party government prevailed more than seventy percent of the time between 1796 and $1945,{ }^{51}$ compared with less than fifty percent of the time since 1945 and less than thirty percent of the time since $1968 .{ }^{52}$ There has

47 See The Federalist No. 51, at 358-59 (J. Madison) (B. Wright ed. 1961). But see R. Bell, Party and Faction in American Politics 3 (1973) ("[Madison] did not use the two terms, party and faction, interchangeably.").

48 See Historical Statistics, supra note 5, at 1083.

19 See id. at 1082.

so See id.

s1 See id. at 1083-84.

${ }^{82}$ See Vital Statistics on CoNGRess, supra note 7, at 34-35 (party affiliation 
been a parallel decline in party loyalty among voters and legislators. Two deductions seem warranted. One is that, whatever the intent of the Framers, the constitutional barriers did not keep party government and party loyalty from predominating for a century and a half. The second is that other factors, in addition to the constitutional barriers, must account for their decline over the last four decades.

Those factors have been widely identified as popular primaries, the explosion of campaign financing costs, the rise of well-financed, single-issue pressure groups, the arrival of television as our primary method of conveying and receiving political information, and the reforms of congressional procedures that have lessened the authority and power of legislative party leaders and of the legislative party caucus.

The party today has become a passive mechanism that individual candidates utilize to win nomination and election. The party's "leaders" no longer select the candidates. They no longer raise or control the allocation of most campaign funds. The presidential and congressional candidates win nomination with little or no help from one another or from the party organization. In the general election, they all stress their own personal qualifications and play down those elements of the party program that disturb important voting groups, and they persuade more than half of all voters to split their tickets. ${ }^{53}$ Those candidates who reach Congress are more independent of party selection, support, and discipline today than at any previous time in our history. That does not mean that they are more independent in the Madisonian sense of being free to vote on every issue in the national interest as each of them sees it. Their former dependence on the party for campaign funds and career advancement has been replaced by dependence on the many singleissue interest groups to whom they must turn to raise the constantly increasing amount of money needed to win and hold their seats. They now owe loyalty not to a party with a reasonably coherent view of the right mix of national policy, but to a variety of narrowly focused pressure groups with disparate and conflicting views.

If you accept this analysis, you will be asking a number of questions. Are these present conditions of loose party ties and a high frequency of divided government merely unintended and unavoidable consequences of the progressive reforms in party and congressional procedures over the last two generations, or are they necessary evolutionary responses in the party system as the social and technological environment has changed? Should we try to rebuild party cohesion and

of members of Congress); Congressional QuaRTERLY INC., supra note 7, at 183-84 (party affiliation of Presidents).

ss See Ranney, supra note 14, at 18. 
party government? Or do the present conditions offer a better way of running this vast and diverse nation as it faces the growing complexities of modern life?

There are no empirical answers to these questions. But I would submit these reasons why the present conditions are not inevitable and why we should make the effort to rebuild:

1. Party government and party cohesion are not anachronisms in modern democratic societies. They exist in many of the other industrial democracies and in a majority of our own states. ${ }^{54}$ The fact that they flourish in these other democracies and in our own state governments is strong evidence that their recent decline in our national government is neither inevitable nor irreversible.

2. Our national government has many more major decisions to make today than ever before. The competing interests involved in each decision are far more complex. We hold government responsible today not merely for the goals set forth in the preamble of the Constitution-to establish justice, insure domestic tranquility, and provide for the national defense-but also for the management of the national and world economies and the defense of the entire free world. Even conservative incumbents now accept this broad mandate.

3. Because of the growing interdependence between our national economy, national security, and domestic tranquility and the economy, security, and tranquility of other nations, many of the decisions our government must make involve reaching and keeping agreements with other governments.

4. Without party cohesion and party government, it is extraordinarily difficult to make major domestic decisions and agreements with other governments, because each decision depends on forming a different cross-party coalition.

5. Without party cohesion and party government, both parties and their elected officials usually condemn the resulting hodgepodge of outcomes, yet manage to avoid being held accountable for them. As we have seen, the ability of incumbents of both parties to shift the blame and win reelection has been phenomenal.

6. If we can succeed in rebuilding a modicum of party government and party cohesion, there is little risk that we will veer from one extreme policy to its opposite, or that significant interest groups will be-

54 In 1982, the same party won the governorship and a majority of both legislative houses in 28 of the 49 states with bicameral legislatures (Nebraska has a nonpartisan unicameral legislature). See 38 Cong. Q. Almanac 13-B (1982). While there are no useful statistical data, anecdotal evidence suggests that party cohesion among members of state legislatures is considerably higher than in Congress. 
come severely disaffected. We had party government for most of the time before World War II, and putting the split over the constitutional entrenchment of slavery to one side, neither of these grievous consequences befell us. In contrast to the United Kingdom, the constitutional role of the Supreme Court limits the extremes to which party government and party cohesion can take us. Justice Roberts' own career is a reminder that the Court will not permit party government to legislate beyond its constitutional powers or to impair basic constitutional rights. ${ }^{55}$ In part because of our diversity and size, but primarily because of the constitutional barriers, party government in America has never been efficient enough to achieve extreme and divisive results.

7. Party government does not assure creative and effective government, but divided government comes close to assuring stagnant and ineffective government. All of the great Presidents-Jefferson, Lincoln, Theodore Roosevelt, Wilson, and Franklin Roosevelt-presided over party governments. ${ }^{56}$ It is hard to think of a single major change of legislative policy in this century-with the exception of the Reagan 1981 tax cuts - that was adopted during a period of divided government, and that change occurred in the brief honeymoon period during the first year of President Reagan's term. ${ }^{57}$

8. A return to party government would not impair the congressional power to oversee executive performance and curb executive excesses. Nor would it restore the arbitrary power of party bosses and legislative leaders. Popular primaries and the democratization of congressional procedures are here to stay. These reforms, together with the penetrating surveillance of the investigative press, are sufficient guarantees that the basic constitutional checks and balances will continue to function. They do not depend on divided government to work. Teapot Dome, for example, was exposed during a time of party government, with Owen Roberts playing the same prosecutor's role that Archibald Cox was to fill in the Watergate scandal half a century later. ${ }^{68}$

If the case for rebuilding party unity and reducing the frequency of divided government is accepted, the easier place to begin is with changes in party and congressional rules and the election laws, rather than with the far more difficult task of adopting constitutional amendments. As I have noted, party government did predominate until after

${ }^{35}$ For a description of Justice Roberts' career on the Supreme Court, see Burner, Owen J. Roberts, in 3 The Justices of THE UnIted States SuPreme Court 17891969 , at 2255-63 (1969).

se See HistoRical Statistics, supra note 5, at 1083-84.

B7 See J. Sundquist, Effective Government and Constitutional Reform ch. 4 (forthcoming publication by The Brookings Institution).

${ }^{\circ 8}$ See Burner, supra note 55, at 2255. 
World War II despite the constitutional barriers. If the recent developments that have led to divided government could be offset by changing these rules and election laws, this would appear to be the place to start.

Six such ideas are worthy of special mention:

1. Amending party rules so as to provide that in the presidential nominating conventions, the winners of the party nominations for the House and Senate, plus the holdover Senators, would be entitled to seats as voting delegates. These five hundred or so additional delegates could have an important influence on the selection of the presidential nominee. This in turn would tend to build greater interdependence and closer party cohesion between the presidential and congressional wings of each party, and identify them more closely together in the voter's mind. ${ }^{\text {se }}$

2. Amending campaign financing laws to create a congressional campaign broadcast fund, similar to the existing Presidential Election Campaign Fund. ${ }^{60}$ This fund would be available to each party and its congressional candidates in the general election for broadcast expenses, on the condition that they not expend any other funds on campaign broadcasts. ${ }^{61}$ Half or more of each party's share would go to the party itself, which could place its bets among its candidates so as to maximize

69 Another version of this idea would involve creating a bicameral nominating convention. One chamber would consist of the party's congressional nominees plus the holdover Senators. The other chamber would consist of the delegates as presently selected in primaries and party caucuses. Nomination would require carrying a majority of each chamber. If the chambers split, there would be a runoff ballot between the two winners determined by the sum of the percentages achieved in each chamber. See Cutler, Getting Rid of Incoherent Government, Washington Post, Mar. 27, 1983, at B1, col. 3.

so 26 U.S.C. $\$ \S 9001-9013$ (1982). Under this statute, each major party nominee is entitled to receive an equal amount for the presidential campaign, on the condition that a nominee accepting federal funds agree not to receive or expend any other funds. See id. $\$ \S 9003($ b), 9004 (a)(1). Minor party nominees are entitled to proportionately lower amounts based on the party's record in the last election, see id. $\S 9004(\mathrm{a})(2)(\mathrm{A})$, but may receive and expend privately raised funds up to the major party ceiling. See id. $\S 9003$ (c). The Supreme Court upheld the constitutionality of this fund, including its limits on other contributions and expenditures, in Buckley v. Valeo, 424 U.S. 1, 90-109 (1976) (per curiam). In the three elections since the statute became effective, both major party candidates have accepted the federal funds.

o1 Broadcast expenses now account for a high percentage of all campaign costs. Ceilings on broadcast expenditures would be the virtual equivalent of ceilings on all expenditures.

The proposed statute could be structured to limit use of the federal funds to live or taped personal appearances by the candidate, in order to bar its use for "canned" political commercials. It might also bar the use of private funds for such commercials by any candidate accepting the public funds. As in the case of the Presidential Election Campaign Fund, however, the statute could not reach expenditures by contribution-supported "independent" committees. See Federal Election Comm'n v. National Conservative Political Action Comm., 105 S. Ct. 1459, 1467-71 (1985). 
its chances to win a majority. ${ }^{62}$ This should help to build party cohesion by making candidates depend on the party for a large part of their campaign funds and by reducing their dependence on raising funds from single-issue interest groups.

3. Providing by federal statute that the presidential elections be conducted two to four weeks before the congressional elections. ${ }^{63}$ This would tend to reduce divided government by enabling voters to know which party has been entrusted with the White House before they vote for members of the House and Senate. While voter participation in a later congressional election might be lower than in the presidential election, ${ }^{64}$ a two-stage election would maximize the new President's chances, in the honeymoon of his own election, to win a majority for his party in the Senate and House, and thus improve the party's chances of carrying out its program. This is what happened in the two-stage French election of $1981 .^{65}$

4. Providing by federal statute that every state must include on its ballot for all federal elections an additional line or lever by which a voter may (but need not) cast a vote for all the candidates of one party for the open federal offices. ${ }^{86}$ Connecticut has such a ballot, and in

62 One possible method might be to allocate $50 \%$ of the public funds directly to each party nominee on a population-based formula and to allocate the other $50 \%$ to each national party organization or its congressional campaign committee. The designated party body could then allocate its share among nominees in the same way it now allocates privately raised funds.

With greater difficulty, the proposed statute's objective might also be achieved by allocating blocks of broadcast time to the candidates and requiring stations, as a condition of their licenses, to provide the time without charge. But the practical problems of allocating time are considerably greater than in the case of money, and the opposition of broadcasters would be severe.

es Under article I, section 4, and article II, section 1, of the Constitution, Congress has clear power to fix the time of elections to federal office, and is free to fix different dates for elections to different offices. See Smiley v. Holm, 285 U.S. 355, 366-67 (1932); Ex parte Yarbrough, 110 U.S. 651, 660-63 (1884).

4. Voter turnout in "midterm" congressional elections is usually lower than in the years of presidential elections. Voter turnout in two-stage state primary elections is also usually lower in the runoff phase, unless the race is expected to be a close one.

os Under the Constitution of the Fifth Republic, the election for the seven-year presidential term is out-of-phase with the election for the five-year Assembly term. However, the President has the power to dissolve Parliament and call for new parliamentary elections. See The Statesman's Year-Book 1985-1986, at 472-73 (J. Paxton ed. 1985). When François Mitterand was elected President in 1981 as the candidate of a Socialist Party-Communist Party coalition, he promptly dissolved Parliament and called for new elections a month after the presidential election. In the parliamentary election, the Socialists won a decisive majority by themselves and did not need the support of the Communist deputies to govern. See N.Y. Times, June 22, 1981, at A1, col. 6 .

Bo Such a statute would clearly be within the authority of Congress to regulate the time, place, and "manner" of elections to federal office. See Smiley v. Holm, 285 U.S. 355, 366-67 (1932); Ex parte Yarbrough, 110 U.S. 651, 660-63 (1884). 
1984 President Reagan's coattails in Connecticut were more effective than in many other states. ${ }^{67}$

5. Providing by party legislative rule that by a sixty-percent vote the party caucus in each house could bind all party members to vote the party position on up to a stated number of particular bills per session. Such a rule could be enforced by automatic loss of any chairmanship or other party office held by a member who votes against the caucus position more than a stated number of times per session. This would be a more moderate version of the binding party caucus so effectively employed in Wilson's first Congress and briefly revived during FDR's first term. ${ }^{68}$ It would greatly enhance party legislative loyalty while leaving reasonable scope for party members to make occasional departures on principle from the party caucus position.

6. Changing the party and legislative rules to create a "Shadow Cabinet" for the party not holding the White House. The Shadow Cabinet would consist of the party's highest ranking member in the House and Senate and on each of from six to ten major House and Senate committees. The House and Senate leaders would alternate annually as leaders of the Shadow Cabinet. The Shadow Cabinet would meet regularly to formulate party positions, and its members would serve as party spokesmen on particular issues. If the House and Senate leaders could be persuaded to form such a cabinet and to make it work, this would go far to build party consciousness in the minds of voters and greater cohesion among the party's legislative members.

These are all rather modest proposals. None of them would shake the foundations of the republic. Singly or in combination, they would not alter the basic political system. But they would somewhat improve the chances of tightening party cohesion and achieving party government.

To improve these chances even more, it would be necessary to lower some of the barriers raised by the Constitution. To amend the Constitution, a two-thirds vote of the House and Senate or the calling of a constitutional convention by two-thirds of the states is required, plus the approval of any specific amendment by the legislatures of three-fourths of the states. ${ }^{69}$ For proposals that would strengthen party cohesion-and thus reduce the individual power of incumbent legisla-

67 Although the Republicans lost 10 House seats nationwide as compared with the 1980 elections, they gained one House seat in Connecticut. See 40 Cong. Q. Almanac 16-B (1984) (1984 election results); 38 Cong. Q. Almanac 18-B (1980) (1980 election results).

se J. SundQuist, supra note 38, at 168-76.

o9 See U.S. CoNST. art. V. 
tors and interest groups-this is a very heavy burden indeed.

That is why the most effective constitutional amendment for restoring party government-the team ticket-is unlikely to get off the ground. Under the team ticket plan, in presidential election years each party would be required to present a slate in each congressional district for all federal offices-President, Vice President, House member, and any open Senate seat-and voters would be required to vote for the entire team of the party of their choice. ${ }^{70}$ It seems unlikely that either congressional incumbents or state legislatures would approve depriving voters of the right to split their tickets.

But there are a few more popular amendment ideas that do not threaten incumbent legislators or curtail voter freedom, and that would further strengthen party cohesion and the prospects of party government, or at least provide a means of breaking the deadlocks that occur under divided government:

1. Providing for four-year terms for House members, running simultaneously with the presidential term. In the version I prefer, the Senate term would also be extended from six to eight years. There would be two classes of Senators instead of the present three. One class would be elected in each presidential election. Simultaneous elections for all federal offices once every four years would increase the potential for party government by eliminating the midterm elections, in which the President's party almost always loses House and Senate seats. With four years between elections, incumbents would have more time to discharge their legislative duties. Their time horizon to the next election would be lengthened to the same four years as the President's, thereby improving the chances of party cohesion and extending the President's "honeymoon" period. Congressional incumbents with at least four years before the next election would be more likely to support programs calculated to impose short-term sacrifices in order to achieve longerterm benefits. President Johnson proposed the four-year congressional term, ${ }^{\mathbf{7 1}}$ and President Reagan is expected to endorse it during his second term.

2. Granting the President discretion to include sitting members of

70 Under the electoral college system, as modified by the twelfth amendment, the Constitution already requires voters to vote for electors who normally cast their ballots for one party's presidential and vice-presidential candidates as a team. In 1984, it was not possible to vote for Reagan and Ferraro, or for Mondale and Bush.

${ }^{71}$ See J. Sundquist, supra note 57 , at ch. 5 . To satisfy possible concerns about the utility of the midterm election as a "referendum" to resolve deadlocks between the President and the opposition party in Congress, the amendment could authorize a midterm election for the balance of the Senate and House terms by action of a majority of both houses or of the President and a majority of one house. 
Congress in his Cabinet without requiring them to give up their seats, something the Constitution now forbids. Chief Justice Story and President Wilson were among the first to propose this step as a way of building party cohesion between the President and the legislators of the same party. ${ }^{72}$

3. A package amendment that would (a) reinstate the constitutionality of a legislative veto of certain presidential and agency actions, subject to presidential veto of the legislative veto and in turn to an override by two-thirds of both houses, ${ }^{73}$ and (b) reduce the requirement for treaty ratification from two-thirds of the Senate to sixty percent or to a simple majority of both houses. This mutual exchange of powers would encourage broader delegations of discretionary authority to the executive, and greatly facilitate the government's ability to make and perform agreements with other nations.

This package could be enlarged to include an amendment authorizing the President to make a "line-item" veto of any bill appropriating expenditures, subject to override by majority vote of both houses, rather than the two-thirds override for a general veto. ${ }^{74} \mathrm{~A}$ line-item veto now exists in most of the states, ${ }^{75}$ and it would be of at least some assistance in breaking deadlocks on how to reduce deficits. The line-item veto has been described as one of President Reagan's "top legislative

72 See S. Horn, The Cabinet and Congress 35, 101 (1960).

73 In Immigration \& Naturalization Serv. v. Chadha, 462 U.S. 919 (1983), the Supreme Court invalidated the one-house legislative veto provision of the Immigration and Nationality Act. See id. at 956-59. The Court's decision, based on the presentment clauses, U.S. CoNST. art. I, § 7, cls. 2 \& 3, sounded "the death knell for nearly 200 other statutory provisions in which Congress [had] reserved a legislative veto." Id. at 967 (White, J., dissenting). The Court could have rested its decision in that case on much narrower grounds, but deliberately chose to strike down all forms of the legislative veto. See id. at 959-60 (Powell, J., concurring).

A two-house veto provision subject to presidential approval or veto, and in turn subject to an override of a veto by two-thirds of both houses-in other words a statute-would of course comply with the presentment clauses and would not require a constitutional amendment.

74 With President Reagan's support, Senator Mattingly of Georgia has recently introduced a bill that would authorize line-item vetoes by statute. See S. 43, 99th Cong., 1st Sess. (1985). It provides that every numbered section and separate paragraph of every subsequent appropriations bill passed by Congress shall automatically be enrolled and presented to the President as a separate bill. See id. The constitutionality of such a statute appears open to considerable doubt. For a discussion of the regulatory and constitutional issues raised by the bill, see Senate Comm. on Rules and Administration, Report to Accompany S. 43, S. REP. No. 92, 99th Cong., 1st Sess. (1985). In any event, future members of Congress could easily frustrate its purposes by writing appropriations bills without numbered sections or separate paragraphs.

75 Forty-three states now have line-item vetoes. SEnate Comm. ON RULES AND ADMINISTRATION, supra note 74 , at 4. 
priorities."76

There is another pair of amendment proposals that would improve the chances of avoiding or breaking deadlocks, but would work a more fundamental change in our present constitutional structure. One such proposal would create a simultaneous five-year term for President and for members of the Senate and House (or a six-year presidential term combined with a three-year House term and a six-year, two-class Senate term). ${ }^{77}$ The most widely advocated proposal of this type would limit the President to a single six-year term. ${ }^{78}$ The second proposal would build on the first. It would compensate for the longer terms by allowing a majority of both houses, or the President plus a majority of one house, to call at any time for new national elections for the presidency and Congress for new full terms. Its supporters urge that, by adopting in modified form this basic feature of most parliamentary systems, the President and Congress would be given an added incentive to avoid deadlocks and a means of breaking them when necessary. They also urge that, in addition to its salutary effect on deadlocks, it would provide a way to turn a weak but nonimpeachable President out of office. $^{79}$

All of these ideas, and others, are now being studied by the Committee on the Constitutional System. The Committee's two hundred members include many present and former legislators, Cabinet members, White House staffers, Governors and Mayors of both parties, and a wide cross-section of academic, business, labor, political, and interest

${ }^{76}$ Dewar, Line Item Veto Bill Shelved After Third Filibuster Vote, Washington Post, July 25, 1985, at A20, col. 1.

${ }_{77}$ A simultaneous five-year term for all elected federal officials would come the closest to a parliamentary system. It is noteworthy, however, that the present Constitution of France, which combines a parliamentary system with even greater powers for the President than provided for in the American Constitution, does not provide for simultaneous terms. It does, however, authorize the President to dissolve Parliament and call for new elections.

A six-year presidential term combined with a three-year House term and a sixyear, two-class Senate term would have the disadvantage that half the Senate would always be elected in a presidential election while the other half would always be elected in a nonpresidential election.

${ }^{78}$ Presidents Eisenhower, Johnson, and Carter have all favored the single sixyear term. The Committee for the Single Six-Year Presidential Term, co-chaired by Milton Eisenhower, William Simon, Cyrus Vance, and Griffin Bell, is now urging a constitutional amendment to bring it about.

${ }^{79}$ See J. Sundquist, supra note 57, at ch. 5. Unless the present method of nominating candidates and conducting general elections were sharply revised, elections following dissolutions would face enormous practical difficulties. Some advocates of a dissolution procedure, noting the high cost and extended length of current campaigns, regard the necessary foreshortening of a post-dissolution election as one of the idea's virtues. 
group leaders. ${ }^{80}$ It is chaired by Senator Nancy Kassebaum, Douglas Dillon, and your speaker this evening. It is proceeding on the theory that a constructive way to commemorate the bicentenary of our constitutional system is to analyze its few weaknesses along with its many strengths, and to consider how those weaknesses might be corrected.

As the Committee proceeds with its analysis, some of the measures I have listed may be judged not potent enough to help restore party cohesion and undivided government or to prevent deadlock. Others may have overriding adverse side effects. Some that pass both these tests, especially the constitutional amendments, may not yet be politically viable. But further analysis may also produce a set of possible changes that are relatively free of such defects and would help to correct the weaknesses we see today. In any event, we will do better by pursuing this analysis than by merely deploring how television and other modern phenomena have changed our political process, ${ }^{\mathbf{8 1}}$ or by continuing to blame what are really the faults of the structure on the individuals we elect to run it. ${ }^{82}$ If the pending call for a constitutional convention to propose a "balance the budget" amendment is joined by the two additional states needed to provide the triggering two-thirds-an outcome we do not favor-our Committee may be ready with some better ideas. $^{\text {ss }}$

Bo The members include Senators Nancy Kassebaum and Daniel Patrick Moynihan; Secretary of Commerce Malcolm Baldrige; former Senators Nicholas Brady and J. William Fulbright; former Congressmen Jonathan Bingham, Richard Bolling, Robert McClory, Henry Reuss, and John Rhodes; former Cabinet members and White House staffers Douglass Cater, William T. Coleman, Jr., Lloyd N. Cutler, C. Douglas Dillon, Henry Fowler, Donald McHenry, Robert McNamara, Rocco Siciliano, and Elmer Staats; state officials Governor Richard Thornburgh and former Governors LeRoy Collins and Linwood Holton; Mayor W. Wilson Goode; political party officials Janet Brown, Lynn Cutler, Elsie Hillman, and Mary Louise Smith; academicians James MacGregor Burns, Gerhard Casper, Ruth Friendly, Alexander Heard, Matthew Holden, A.E. Dick Howard, Nancy Altman Lupu, Bruce MacLaury, Martin Meyerson, Norman Ornstein, Kevin Phillips, Donald Robinson, Donna Shalala, and James Sundquist; and civil leaders Jessie Rattley, Glenn Watts, and Walter Cronkite.

81 See Cutler, Foreign Policy on Deadline, 56 ForeIGN PoL'y 113, 118 (1984) (impact of television news on national policy decisions much greater today).

${ }^{82}$ See Cutler, To Form A Government, 59 Foreign AfF. 126, 128 (1980) (We cannot hold the President responsible for his overall program because he lacks the constitutional power to put it into effect.).

8s No constitutional convention has ever been called under article $V$, and no statutory procedure for organizing such a convention now exists. Although an organizing bill reported out last year by the Senate Committee on the Judiciary purports to limit the subject matter jurisdiction of a constitutional convention, leading scholars and several members of the Committee have expressed the view that such limits are probably unconstitutional. See Senate Comm. ON THE Judiciary, Constitutional ConvenTION IMPLEMENTATion ACT of 1984, S. ReP. No. 594, 98th Cong., 2d Sess. 11, 13 (1984); Dellinger, The Legitimacy of Constitutional Change: Rethinking the Amendment Process, 97 HARv. L. REv. 386, 399-400 (1983). 
What would Justice Owen Roberts have thought about the need for restoring party government and party cohesion, and of the various proposals I have described? He despised junk amendments to the Constitution, such as prohibition, and he probably would feel the same way about the current amendment proposals to balance the budget and to prohibit abortions. ${ }^{84}$ But as I noted at the beginning, he was also a fervent advocate of the Atlantic Union, and therefore a man who was not afraid to consider adapting our political structure-even the Constitution itself-to accommodate the complexity and interdependence of modern life. In 1950, Justice Roberts was a coauthor of The New Federalist, ${ }^{\mathbf{8 5}}$ which expounded the case for an international convention to draft a constitution creating a federal union of the world's major democracies. The New Federalist recognized the importance of political parties and accountable party government. It envisioned that a transnational party or parties would win a majority of the Federal Union Congress and that a member of the majority would be selected as the federal executive. Indeed, it went so far toward insuring accountability as to propose that the executive would have to resign if he lost a congressional vote of confidence, and that new elections could be called if a deadlock occurred.$^{86}$ Implicitly, it recognized that to accommodate the transfer of sovereignty to the new Federal Union, our own Constitution would have to be modified in ways more fundamental than any I have mentioned.

We cannot know whether Justice Roberts would have agreed with what I have said about the need to adapt our national political structure so as to encourage party government and party cohesion. In his time the problem was not a serious one. But I venture to suggest that if he had witnessed the last forty years he would have been interested enough to become an active member of our committee, and that if he accepted our analysis of the problem, he would not have drawn back from advocating the structural changes needed to solve it.

84 Burner, supra note 55, at 2255 (noting Owen Roberts' alleged statement that "[p]rohibition has no place in the Constitution").

${ }^{85}$ O. Roberts, J. Schmidt \& C. STREIT, supra note 2.

${ }^{86}$ See id. at 65-66. 